JRIT

15,1

2

Received 29 December 2019 Revised 20 July 2020 Accepted 7 August 2020

\section{Individual innovativeness, self- efficacy and e-learning readiness of students of Yenagoa study centre, National Open University of Nigeria}

\author{
Gordon Monday Bubou \\ Department of Science Policy and Innovation Studies, \\ National Center for Technology Management, South-South Office, \\ Amassoma, Nigeria and \\ Faculty of Education, National Open University of Nigeria, Abuja, Nigeria, and \\ Gabriel Chibuzor Job \\ Department of Educational Foundations, National Open University of Nigeria, \\ Abuja, Nigeria
}

\begin{abstract}
Purpose - The purpose of this study is to explore the role individual innovativeness along with e-learning selfefficacy play in predicting the e-learning readiness of first- and second-year students of an open and distance education institutions in an African context.

Design/methodology/approach - Therefore, building on previous related research in this area, a quantitative approach was adopted to address the research questions and to establish whether a statistically significant relationship existed between individual innovativeness, e-learning self-efficacy, the independent variables; and e-learning readiness, the dependent variable. In total, 476 first- and second-years students of the university participated in the four-Likert-type scale survey. The research instrument which comprises 74 survey items was completed by 217 of the students. Statistical tools used for analysing data included both Pearson Product Moment Correlation coefficients and $t$-tests.

Findings - It was discovered that a strong positive and significant relationship was observed between individual innovativeness and e-learning readiness of first- and second-year students of the Yenagoa Study Centre of the National Open University of Nigeria (NOUN); a statistically significant relationship was also found between e-learning selfefficacy scores and the e-learning readiness of the first- and second-year students of the Yenagoa Study Centre of NOUN; there was a statistically significant joint relationship between the three variables under investigation; findings equally revealed that male respondents had higher e-learning readiness than their female counterparts.

Research limitations/implications - Like every other study of this nature, this one also suffers some limitations. First, NOUN is a very large university with over half a million students spread across almost 78 study centres. This means that observation from just one study centre amounts to a very small sample size. This according to Schweighofer, Weitlaner, Ebner and Rothe (2019) jeopardises the generalisability and validity of study results. The authors also maintain that empirical data generated from surveys that usually rely participants' abilities to read and select responses without further interpretation by the researchers suffer from cognitive biases like social
\end{abstract}

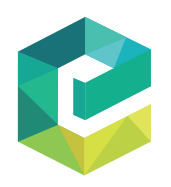

Journal of Research in Innovative Teaching \& Learning Vol. 15 No. 1,2022 pp. $2-22$ Emerald Publishing Limited 2397-7604

DOI 10.1108/JRIT-12-2019-0079

\footnotetext{
(C) Gordon Monday Bubou and Gabriel Chibuzor Job. Published in Journal of Research in Innovative Teaching \& Learning. Published by Emerald Publishing Limited. This article is published under the Creative Commons Attribution (CC BY 4.0) licence. Anyone may reproduce, distribute, translate and create derivative works of this article (for both commercial and non-commercial purposes), subject to full attribution to the original publication and authors. The full terms of this licence may be seen at http:// creativecommons.org/licences/by/4.0/legalcode

The authors remain grateful to the anonymous reviewers who provided valuable suggestions that led to the improvement of this paper. The authors also thank the students of NOUN, Yenagoa Study Centre who freely participated in the survey.
} 
desirability. To address the above limitations, detailed studies involving all studies centres of NOUN be undertaken and other qualitative and or mixed research methodologies be adopted in the future.

Practical implications - The implications for this study are that people who are innately innovative will willingly accept technology and by extension, learning in technology-rich environments like those found in like NOUN whose mode of study is blended learning inherently found in open and distance learning (ODL) institution. Therefore, this study is significant as it will provide relevant information to the management and administrators of NOUN, policymakers and regulatory institutions for the development, deployment and implementation of e-learning strategies. Findings will also benefit e-learning initiatives undertaken by similar institutions that adopt the ODL mode of education in Nigeria and other developing countries.

Originality/value - Even though, studies on the antecedents of e-learning readiness have been widely conducted across diverse contexts, studies exploring the associations between individual innovativeness, elearning self-efficacy and e-learning readiness are relatively hard to come by. The above two variables as predicting the e-learning readiness in the study context are comparatively new. This study thus focuses on the relationships between the individual innovativeness levels, e-learning self-efficacy beliefs of students and their e-learning readiness which ultimately determines their ability to sustain studies in an ODL institution.

Keywords Open and distance education, Individual innovativeness, Technology-enhanced learning, e-learning learning readiness, e-learning self-efficacy, Innovations in education

Paper type Research paper

\section{Introduction}

Twenty-first century education has been inundated with seismic pedagogical shifts due in part to the rapid advances in technology witnessed in the last three decennia, especially as a result of the boom in information and communications technologies (ICTs) such as the Internet (Ditimi and Ayanda, 2013; Musaka, 2015; Yunusa et al., 2019). Such shifts are the result of the use of the Internet and other digital technologies to enhance human learning. In fact, technology-enhanced learning (TEL) approaches have become widespread in the higher education subsector (Schweighofer et al., 2019) and have further escalated since the emergence of the novel corona virus 2019 (COVID-19). The current rise in the rate of development and deployment of different TEL approaches, particularly electronic learning (e-learning) by several organisations, including tertiary institutions, is reinforced by the desire to solve authentic, teaching, learning and performance problems.

Despite the over 170 universities, 149 colleges of education and the over 300 polytechnics, colleges and specialised institutions (National Board for Technical Education, 2019; National Commission for Colleges of Education, 2019; Nigerian Universities Commission, 2019), Nigeria stills struggles to cater for the teeming needs for tertiary admissions. A recent report from the Nigerian Bureau of Statistics (NBS) revealed the Joint Admissions and Matriculations Board received a total number of 1,653,127 and 1,722,269 in 2018 and 2017 respectively (NBS, 2019). The same report further indicated that out of those thousands of admission seekers, only 549,763 and 566,719 got admitted into the universities in 2018 and 2017 respectively. This leaves a shortfall of over one million admission seekers. This has been the trend for the last decennia (Ekundayo and Ekundayo, 2009) and there seems to be no end in sight.

The National Open University of Nigeria (NOUN) was established to tackle the challenges of inadequate capacity within the Nigerian higher education sector by providing quality affordable tertiary education to majority of Nigerians through the open and distance learning (ODL) mode. As the only singly ODL mode government-owned institution, NOUN has deployed several technologies, tools and platforms to facilitate e-learning. NOUN offers over 50 programmes and 750 courses, thereby bringing quality education and an enriched learning experience to the doorsteps of nearly every Nigerian (Olowonisi, 2016). An agency report quoted the Vice Chancellor of the University as hinting that more than half a million students were currently enrolled at NOUN and that the university intends to further increase enrolments up to a million students (Omoike, 2020; Premium Times, 2018). However, the same report indicated that only $30 \%$ of those students were active across the 78 study centres of the University. Thus, the new challenge now is how to make those non-active students become active in the studies.

\section{Innovativeness, self-efficacy and e-learning}


JRIT

15,1

4

The integration of learning technologies into the educational arena may not necessarily mean that the intended end users, teachers and learners are really going to use them. But the benefits of electronic learning systems (ELS) can only be maximised when teachers and learners use such systems (Pituch and Lee, 2006). Equally, part of the issues surrounding the smooth take off and operations of ELS has been that of readiness in terms of the teachers, learners, organisations and the technology itself. For instance, electronic learning readiness (ELR) has been recognised as both a crucial factor influencing the uptake of e-learning in institutions and a critical component to successfully implement e-learning programmes in HEIs (Rohayani et al., 2015).

Some of such studies indicate that Nigeria ranks 62 among nations in terms of institutional e-readiness which is way below that of South Africa and Egypt who ranked 39 and 57 respectively (Kyari et al., 2018). In a related development, a study on e-readiness and educational development of some private universities in Nigeria revealed that, e-learning readiness of the students was low (Ditimi and Ayanda, 2013). This further underscores the necessity of seeking innovative solutions to expand e-learning adoption in the country (Kyari et al., 2018).

Diverse factors interact in determining achievements in ELS and those aspects need to be considered to design efficient ELS (Nyagorme, 2014; Salloum et al., 2019). For this reason, several studies have been conducted to identify potential causes of failure of e-learning adoption and possibly find solutions to the challenges. In fact, Lai (2008) maintains that, the success of the ELS hinges not only on the acceptance to use the technology but also on, among other factors, the user's technology readiness as well as their Internet self-efficacy. Yi et al. (2006) also confirmed that more two decennia of research has been directed at identifying salient perceptions of some other prominent technology attributes like innovation characteristics which impact on users' decisions to accept technology.

Whereas numerous studies have been undertaken to investigate the e-learning readiness in HEIs globally and in Nigeria, including NOUN, most of the studies only focused on the organisational or institutional level of ELR and typically dwelled on the aspects of technological and human resource readiness. Less is reported on the learner aspects of ELR. Likewise, there has been little or no attempt to associate students' individual innovativeness and e-learning self-efficacy with e-learning readiness in ODL education research. Yi et al. (2006) admits that only relatively few studies examined the potential impacts of users' individual innovativeness on perceived decisions to accept or use technology. It is the intention of this study to bridge this knowledge gap by investigating those relationships among these variables at the Yenagoa Study Centre of NOUN with a view to broadening the scope of the study to include all students of NOUN.

Thus, to harness the full potential of e-learning as an educational strategy to increase broader access to tertiary education in Nigeria, to augment classroom instruction and to eventually intensify students' learning outcomes in ODL institutions like NOUN, it is of great significance that we investigate the role individual innovativeness and self-efficacy, particularly role technology (e-learning) self-efficacy play towards learners' adoption of e-learning at NOUN.

\section{Literature review \\ E-learning readiness}

For learning institutions to successfully integrate and realise the benefit of technology as a learning aid and teaching tool, it requires not only physical infrastructure and technical expertise but also some level of psychological readiness is required (Ouma et al., 2013). The authors insist that learners must also be "e-ready" so that a coherent achievable strategy tailored to meet their needs may be implemented. It is true because learners' readiness in 
online learning environments (OLEs) is vital for them to be able follow through the learning process quite easily and properly (Rahardjo, 2018). Additionally, institutions need to evaluate their e-learning readiness levels (Adiyarta et al., 2018). This is because readiness of learners to actively engage in e-learning and the availability of an enabling OLE are both essential for the success of e-learning programmes and courses (Obi et al., 2018).

It is stated that, conceptualising ELR is crucial because it delineates the parameters of its applicability in a study as well as provides a clear framework for a research study (Oketch et al., 2014) in any given context. For instance, Borotis and Poulymenakou (2004) defined ELR as the "mental or physical preparedness of an organization for some e-learning experience or action" (p. 1622). Likewise, Parlakkıllı̧ (2015) referred to online learning style readiness as: "users' online learning style readiness defined as the readiness of the learner or trainee in terms of time commitment to e-learning, discipline and interest in e-learning and the perception of the status of qualifications obtained via e-learning" (p. 60).

Again, ELR includes learners' ability to acclimatise to technical challenge, adjust to collaborative training and either for asynchronous and/ or synchronous self-paced study (Schreurs et al., 2008). Therefore, in this study context, e-learning readiness is the preparedness of the students of the Yenagoa Study Centre of the National Open University of Nigeria, to fully explore and exploit the learning opportunities provided by ICT and its related learning technologies, and ultimately to maximally draw the attendant benefits in terms of students' academic achievements, reduced dropout rates, social connectivism and for lifelong learning.

\section{Individual innovativeness and innovativeness theory}

Gilbert (2007) described innovativeness as encompassing "the concepts of newness in systems, processes, products and services, behavioural change, environmental adaptation, and learning and knowledge development; all of which occurs in context over time" (p. 3). Similarly, Rogers (1995) defined innovativeness as the degree to which an individual adopts new ideas relatively earlier than others within a system - in this case - with an e-learning environment. Again, Çelik (2013) regard innovativeness as an umbrella concept that can mean risk-taking, openness to experiences, creativeness and though leadership and that individuals have different experiences with and orientations towards innovativeness. These unique individual differences in orientations towards innovativeness are what is referred to as individual innovativeness. It is almost a consistent character trait of an individual that reflects the person's underlying nature when introduced to an innovation (Yi et al., 2006).

According to Agarwal et al. (1998), first introduced in 1998, the construct of Personal Innovativeness in the Domain of Information Technology was designed to measure "the willingness of an individual to try out any new information technology" (Agarwal et al., 1998). Furthermore, Hurt et al. (1977) considered it as a normally distributed, underlying personality construct that could be construed as a readiness to change. Readiness to change includes being able to adopt, adapt and survive new learning environments like ELS. Also, individual innovativeness is viewed as a significant aspect in developing positive attitudes towards the new technology use (Ayub et al., 2017). New technology in this case can mean e-learning.

The Individual Innovativeness Theory propounded by Rogers (1995) proposes that individuals tend to react differently to changes that depended on certain traits or predispositions. It focuses on the idea of being adoptive and adaptive to changes, by willing to take risks unlike most others (Bautista et al., 2018). These characteristics make those individuals to accept innovations earlier than others, as they are more or less open to change, and are willing to take more or less risk (Adigüzel, 2012; Coklar, 2012; Gürkan and Demiralay, 2016; Martins, 2018; Rogers, 1995; Yilmaz and Bayraktar, 2014). Furthermore, the theory suggests that, "some individuals are more innovative than others and for this reason will 
JRIT

15,1

adopt an innovation earlier than the majority of the group" (Martins, 2018). It also means that such individuals have different degrees of innovations' adaptations (Coklar, 2012; Gürkan and Demiralay, 2016). Martins (2018) maintains that individual innovativeness theory has proven to be a useful tool in developing near- and long-term strategic plans geared towards improving technology integration in schools, particularly in higher educational institutions. Thus, this research tries to explore the relationships between the five individual innovativeness categories of first- and second-years students of the Yenagoa Study Centre of NOUN and their perceived e-learning readiness.

\section{E-learning self-efficacy and self-efficacy theory}

A review of the extant literature led some researchers to the conclusion that learning theories like - behaviourism, social constructivism, social learning theory, social exclusion and social connectivism, self-determination, self-efficacy and cognitivism readily offers a deeper understanding of the workings of virtual learning environments (VLEs), including teachers, leaners and course contents (Bawa, 2016; Drumm, 2019). These learning theories are indeed frequently used to conceptualise, model and even proselytise the application of digital technologies in education (Drumm, 2019). Furthermore, most of these sociological theories explicate learner behaviours in electronic learning contexts as potential predictors and possible precursors of problems and solutions relating to VLEs (Bawa, 2016).

Equally, theories on motivation are essential to investigating e-learning readiness of students. This assertion is supported by Bawa (2016) who opine that theories on motivation that deal with self-determination and self-efficacy were relevant to examining learners within ELEs. Interestingly, one vital aspect of motivation is self-efficacy (Zimmerman and Kulikowich, 2016). Furthermore, Shea and Bidjerano (2010) posit that, for the fact that self-efficacy was crucial in elucidating active and successful learners especially in OLEs, the construct was essential to the development of a theoretical framework for electronic or technology mediated education where, in asynchronous learning situations, learner agency may be much more relevant. Compelling evidence from educational research suggests that student self-efficacy is an influential construct that significantly explicates differences in student learning outcomes (Shea and Bidjerano, 2010; Sadi and Uyar, 2013; Prior et al., 2016) and actually makes positive contribution to learning outcomes (Sadi and Uyar, 2013; Yokoyama, 2019).

While the construct of self-efficacy has a relatively long history (Shea and Bidjerano, 2010). Nevertheless, the theory of self-efficacy reportedly originated from Social Cognitive theory hypothesised by Alberta Bandura (Frank, 2001; Shea and Bidjerano, 2010; Yokoyama, 2019). According to Bandura (1982a), an individual's self-efficacy beliefs were closely related to his/her behaviours because they play a significant role in the formation of their attitudes. It might be understood as a crucial mechanism accounting for the interactive relationship between internal pressures and external stimuli that affect human behaviour (Lee and Mendlinger, 2011). It is that personal aspect of the individual that accounts for why he or she engages in a given task (Puzziferro, 2008).

Generally speaking, by relying on the above theory-driven assumptions Self-Efficacy Theory hypothesises a bidirectional influence between self-efficacy and learning outcomes (Olivier et al., 2019). But because self-efficacy is an important determinant of learning success, it has now become an essential part of a successful e-learning experience (Prior et al., 2016). The self-efficacy theory thus has particular significance to e-learning (Puzziferro, 2008). Therefore, this study focuses on the self-efficacy construct as it relates to a person's belief in him/herself as possessing the capacity effectively adopt, use and apply e-learning technologies and efficient function in digital, online or e-learning environments.

Self-efficacy which is closely related to self-worth and self-esteem indicates an individual's level of belief in his or herself concerning a particular situation or thing. It can also be likened 
to one's self-confidence concerning his or her capacity to doing things and attending to particularly challenging situations in life. Bandura (1994) defined perceived self-efficacy "as people's beliefs about their capabilities to produce designated levels of performance that exercise influence over events that affect their lives" (p. 71). Likewise, it is viewed as an individual's confidence in his/her own competence (Christensen and Knezek, 2015) and normally corresponds to the degree of competence an individual perceives of him/herself (Frank, 2019).

Here in this study, the term self-efficacy is defined "as an individual's perceived believe in capabilities he/she possesses that empowers him/her to complete assignments or achieve goals he/she had set for him/herself".

Frank (2001) averred that situational individual self-efficacy results from potential attributions principal among which is previous performance experiences. It was further stated that previous performances and experiences significantly affect the development of an individual's self-efficacy (Schunk, 1995; Frank, 2001). From this perspective, the ability to effectively use ICT (hardware and software) infrastructure depended on the users' technology self-efficacy, because the lack thereof could constrain their inclination to adopt the technology (Mooij and Smeets, 2001).

Furthermore, self-efficacy is domain, context, content and task specific (Bandura, 1997; Hong et al., 2019; Olivier et al., 2019; Quintero, 2020; Taipjutorus et al., 2012b; Kelly, 2017; Yokoyama, 2019). It is actually the personal determination of a person's own capacity to deal with certain tasks (Puzziferro, 2008; Taipjutorus et al., 2012b). Equally, content-specific selfefficacy has been discovered to explicate variance in the link between prior capability (aptitude) and performance (Shea and Bidjerano, 2010). Thus, it is suggested that it was more analytical to use application-specific self-efficacy to explicate learning outcomes and sustained learning activities of students, particularly in e-learning environments (Chu and Tsai, 2009). Accordingly, scholars researching on the theory of self-efficacy emphasise that self-efficacy beliefs should be assessed in such a way that the beliefs correspond to the target performance and contexts or situation of interest (Joo et al., 2000).

In light of the above, countless scholars have undertaken self-efficacy studies from several perspectives, contexts and or domains: academic self-efficacy (Joo et al., 2000; Yokoyama, 2019). Technology self-efficacy, technology and communication self-efficacy, computer selfefficacy (Musaka, 2015; Nardi and Ranieri, 2019; Yildiz Durak, 2018) and other related concepts - online technology self-efficacy, Internet self-efficacy, web-based learning selfefficacy and online learning self-efficacy have been severally investigated (Chen, 2014; Hodges, 2008; Joo et al., 2000; Lai, 2008; Chu and Tsai, 2009; Hong et al., 2019; Taipjutorus et al., 2012a, b; Zimmerman and Kulikowich, 2016). Lastly, studies on e-learning self-efficacy which is the focus of the current study were also undertaken by some scholars (Nyagorme, 2014).

Musaka (2015) defines technology self-efficacy as "personal belief in one's ability to successfully use technology to increase learning outcomes". Yildiz Durak (2018) opined that technology self-efficacy was necessary for learners to effectively participate in an e-learning environment, that is, accessing lecture materials, using virtual instructional tools appropriately, interaction with teachers and peers, engaging in discussions as well as problem solving. In this light, Yildiz Durak (2018) similarly indicated that a learner's technology and communication self-efficacy was related to his/her attitudes towards programming. Likewise, Zimmerman and Kulikowich (2016) referred to online learning selfefficacy "as an individual's perceptions of his or her abilities to successfully complete specific tasks required of online learners".

Similarly, Lee and Mendlinger (2011) assert that, to a large extent, online learning selfefficacy, which is a situation-specific form of efficacy, refers to a person's perception of his or her capabilities to use online learning systems like the Internet, computers and web-based

Innovativeness, self-efficacy and e-learning 
JRIT

15,1

8

instructional materials and other instructional media. Likewise, online learning self-efficacy was denoted to as a learner's self-judgment about his/her abilities to complete an online programme and this is vital for their satisfaction with an online programme (Shen et al., 2013). Based on the theoretical clarifications, it then suggests that, "e-learning self-efficacy" is the belief individuals have in the capabilities they possess that empowers them to successfully undertake studies using e-learning technologies, persist in their studies and ultimate achieve better learning outcomes. This particular situational and context-specific self-efficacy forms the crux of this investigation.

\section{Hypotheses development}

The link between individual innovativeness and e-learning readiness has been investigated in previous studies. For example, Kilicer et al. (2018) averred that past scholarly works have revealed that relationships exist between technology and innovativeness within educational contexts, particularly when it comes to adoption of educational technologies. Again, in their study relating to workers, Hendarman and Cantner (2018) referred to individual innovativeness as the demonstrated worker behaviours directed at engaging innovative activities at the workplace. Similarly, in this study, learners' individual innovativeness relates to demonstrable learner's behaviours that is directed at engaging in innovative learning activities, including being actively involved in online learning environments. Furthermore, Campbell and Ma (2015 as cited by Salloum et al., 2019) discovered that acceptance of e-resources such as eBooks was influenced by technology innovativeness and exposure to e-learning systems. They opine that innovativeness was a possible significant determinant of intent to use - in this case - e-learning adoption.

It is further argued that individual innovativeness potentially contributes to increase a person's technology readiness which again is a predictor of e-learning readiness (Lai, 2008). For example, in their study of IT-based innovations in the healthcare sector, Park and Kim (2010) assumed that individual innovativeness directly determines actual IT adoption behaviours of healthcare practitioners. Their study indeed confirmed that individual innovativeness was critical to understanding IT adoption behaviours of individuals. According to Lai (2008), the innovativeness dimension of the overall technology readiness concept refers to "the extent to which a person believes that he or she is a thought leader, and at the forefront of trying out new technology-based products/services" (p. 19). Additionally, higher levels of individual innovativeness predicted the acceptance and use of e-learning platforms (Kilicer et al., 2018). Based on the forgone, the following hypothesis is proposed for testing in this study:

H1. There is no significant relationship between individual innovativeness and e-learning readiness of first- and second-year students of the Yenagoa Study Centre of NOUN.

Contrary to being inclined towards individualistic tendencies, it has been asserted that individuals with high self-efficacies are said to be well-suited for e-learning environments because such persons are cooperative, accommodating, enthusiastic to share in social situations and are more than ready to tackle difficult tasks instead of avoiding them (Chen, 2014). Some scholars claim that such individuals also are more likely to persist in their efforts with virtually no apprehensiveness until they succeed, even when threatening tasks are performed (Bandura, 1982b, 1994; Kelly, 2017). Additionally, empirical evidence adduces that the higher or stronger an individual's perceived self-efficacy, the more active the person's coping efforts which equally creates impetus for learning (Bandura, 1977, 1982b; 1994; Bandura and Adams, 1977; Hodges, 2008; Lee and Mendlinger, 2011; Sadi and Uyar, 2013; Shen et al., 2013). It also has the tendency to foster learners' confidence and autonomy which empowers them to better perform academically (Bai, 2017; Shea and Bidjerano, 2010; Shen et al., 2013). Again, they are actually 
more likely to be cognitively engaged in learning. It implies, those with high self-efficacy can persist through the rigours of the e-learning environment (Sadi and Uyar, 2013).

Consequently, it can be said that the effective use of an e-learning systems in tertiary institutions is not only influenced by the technology or even system design features but also by the user's ability to use the system effectively in a learning process especially in e-learning environments (Nyagorme, 2018). This is because those with higher self-efficacy tend to more dynamically explore e-learning systems, while those who are low in it seem to withdraw and probably concentrate on simply locating information (Joo et al., 2000).

For this reason, it was necessary to explore the factors that impact on a person's perceived self-efficacy and apply the construct directly to e-learning instructional settings (Vilkas and McCabe, 2014). Likewise, Salomon's (as cited by Bandura, 1982b) study discovered that learners' high perceived self-was associated with heavy investment of cognitive effort and superior learning from instructional media. This reduces the attrition rate among online learners. On the contrary, people who are lacking in self-efficacy although they know what to do have a tendency to behave indecisively (Bandura, 1982b) as such persons are inclined to the idea that difficult tasks are beyond their competences and are also more likely to lose confidence in their capabilities (Bandura, 1977) and are less likely to achieve positive learning outcomes (Shen et al., 2013). Hence, in the opinion of Taipjutorus et al. (2012b), e-learning courses ought to be designed to help students so that their self-efficacy is enhanced and sustained. Going by the theoretical underpinnings of the study, evidence abound in the literature, that among other antecedent factors, individual innovativeness and self-efficacy were critical to learner's surviving in e-learning environments and ultimately achieving their academic goals. Again, as earlier highlighted, since self-efficacy is task, context specific, it is argued that higher levels of self-efficacy in one domain or task may not automatically translate into another (Quintero, 2020). Accordingly, the following hypothesis is proposed:

H2. There is no significant relationship between the e-learning self-efficacy and e-learning readiness of first- and second-year students of the Yenagoa Study Centre of NOUN.

An analysis of the extant literature reveals lots of studies on the adoption and diffusion of innovations (Aydin and Tasci, 2005). Incidentally, only few studies have examined the relationship between individual innovativeness and one's perceived self-efficacy (Çelik, 2013). Thus, like Çelik's (2013) study, this research also attempts to determine how learners' individual innovativeness correlates with their e-learning self-efficacy. Ayub et al. (2017) opined that previous studies have indeed found a link between self-efficacy, individual innovativeness and attitudes towards e-learning readiness.

Here in this study, the relationship among the three variables is symbolised in the path diagram in Figure 1.

The path diagram presupposes that learners with high self-efficacy possess high innovativeness as they are more open to new ideas and are more willing to undertake studies in innovative instructional media, experiment with new digital technologies to meet their learning needs. The model thus argues that individuals who are high innovators and possess high levels of e-learning self-efficacy will be able to adopt, adapt and utilise e-learning media and succeed in their academic endeavours at the Yenagoa Study Centre of the National Open University of Nigeria.

H3. There is no joint relationship between individual innovativeness, self-efficacy and the e-learning readiness of first- and second-year students of the Yenagoa Study Centre of NOUN.

Gender refers to either of the two sexes, male or female. However, unlike sex, gender does not only concern the biological differences between man and woman but encompasses the

Innovativeness, self-efficacy and e-learning 
JRIT

15,1

10

psychological, social and cultural differences between the male and female sexes (Omoyibo et al., 2010). The fact remains that men and women perceive technology differently in any given sociotechnical settings. Sometimes men prefer to adopt certain technologies faster than women and vice-versa. In fact, there is tendency for men to adopt technology earlier than females (Aldahdouh et al., 2020). This could explain why men and women tend to adopt technology differently.

Incidentally, gender is considered as major intervening variable in most educational studies. Several studies reviewed by Okagbue et al. (2020) gender differences and that of age are frequently investigated studies on cognitive abilities. In fact, Ramírez-Correa et al. (2015) mentioned that the extant literature has often presented gender as a moderating variable of the Technology Acceptance Model, particularly within the context of e-learning. Such studies often support the idea that the gender has effect on the association towards the intent to use ICT as well as towards e-learning readiness (Naresh et al., 2016). Also, gender differences are regarded as playing a significant role in e-learning (Ong and Lai, 2006).

However, empirical evidence from numerous studies that have been undertaken to find out if gender differences influence either the e-learning readiness of learners or their perceptions towards e-learning environments have yielded conflicting results. For instance, while a few studies on higher educational institutions found significant relationship between gender and the tendency to accept e-learning (Adams et al., 2018; Formoso, 2018; GonzálezGómez et al., 2012; Naresh et al., 2016; Walia et al., 2019). On the other hand, findings from several other studies show no significant association between gender and e-learning acceptance (Gay, 2018; Oketch et al., 2014; Ramírez-Correa et al., 2015; Rasouli et al., 2016). To further authenticate either side of the argument, this study investigated the influence of gender on NOUN, Yenagoa Study Centre's first- and second-year students' perceptions of e-learning readiness.

H4. There is no significance difference in the e-learning readiness of male and female students of the Yenagoa Study Centre of NOUN.

\section{Methods and design approaches \\ Research design}

The research design of this study will be based on several other previous studies (see for example: Nyagorme, 2018; Obi et al., 2018) by adopting a descriptive analytical research design with a cross-sectional survey method to understand the level of students' e-learning readiness of the students to participate effectively in an ELS. Another aspect of the survey was to investigate the relationship among the three main variables, individual innovativeness, self-efficacy and e-learning readiness.

\section{Sampling frame and data collection methods}

The population of the study consisted of 476 first- and second-year students currently enrolled for undergraduate studies at the Yenagoa Study Centre of NOUN. Out of that number, 227 which about $48 \%$ of the sampling frame was all first-year students while

Figure 1.

The path diagram of the relationship between individual innovativeness, selfefficacy and e-learning

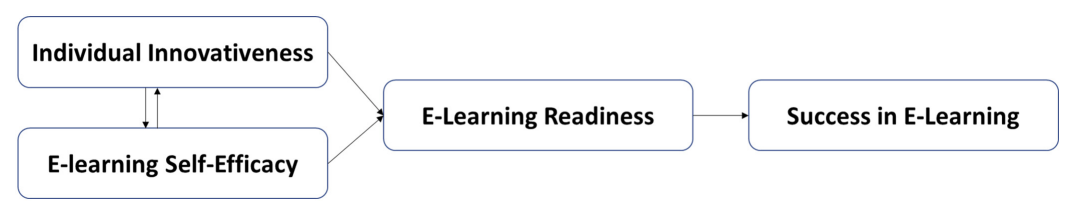


remaining 249 , that is, $52 \%$ of them were all second-year students of the above-mentioned study centre.

Data were collected through a hardcopy survey questionnaire that was distributed to all the students. The distribution and retrieval of questionnaires lasted for two months, from September to October 2019.

\section{Instrumentation}

The research instrument was designed through a methodological and rigorous process, examining and matching the extant literature on electronic learning and the theories on individual innovativeness and self-efficacy. Thus, like the works of many other scholars (Adiyarta et al., 2018; Aydin and Tasci, 2005; Chen, 2014; Hashim and Tasir, 2014; Joo et al., 2000; Nyagorme, 2014; Prior et al., 2016; Taipjutorus et al., 2012a; Zimmerman and Kulikowich, 2016) the research instrument for this study contains multi-item scales which were constructed by adapting items generated from the extant literature which were previously validated tools that were used to investigate the associations among individual innovativeness, e-learning self-efficacy and e-learning readiness. A total of 74 survey items spread across four sections: Section A - demographic data; Section B - questions on e-learning readiness; Section C - questions on individual innovativeness; and Section D e-learning self-efficacy (ELSE) survey questions.

Section A contains 4 items that capture demographic data of the respondents including: gender, age range, year of study and self-reported previous use of e-learning systems (computers, e-mails, Web 2.0 tools, etc.). Section B consisted of 30 items to assess respondents' self-reported perceptions of their e-learning readiness from five factors: technological readiness, culture readiness, content readiness, attitude readiness and demographic characteristics. However, ELR measurement scales were adapted from measurement tools included: e-Learning Readiness Survey (e-LRS) (Aydin and Tasci, 2005; Hashim and Tasir, 2014). Section $C$ contained all 20 items of the Individual Innovativeness Scale developed in 2013 by Hurt, Joseph and Cook. Section D dealt with e-learning self-efficacy. This section contained 20 survey items that were adapted from the following tools used in previous studies: the general self-efficacy survey (Schwarzer and Jerusalem, 1995), Self-Efficacy Formative Questionnaire (Gaumer Erickson and Noonan, 2018), the online technologies selfefficacy scale (OTSES) (Miltiadou and Ho, 2000; Puzziferro, 2008), the learner Internet selfefficacy scale (Joo et al., 2000), the web-based learning self-efficacy (WLSE) survey (Chen, 2014), the online learning self-efficacy scale (OLSES) (Taipjutorus et al., 2012a; Shen et al., 2013; Zimmerman and Kulikowich, 2016) and the ELSE (Nyagorme, 2014).

\section{Data analysis}

Statistical tools used for analysing the collected data in the study included both descriptive inferential statistical tools. In specific terms, research hypotheses one and two were analysed by employing Pearson Product Moment Correlation (PPMC). Research hypothesis (H3) was analysed using multiple regression statistics and $t$-test was adopted to test hypotheses four and five.

\section{Results \\ Validity and reliability of instrument}

The instrument was face-validated by the research supervisor and also by a measurement and evaluation (test) expert in one of the universities within the locality. This validation procedure was aimed at checking the content and overall format of the research instrument, including individual items, the wordings and statements used. Furthermore, a draft of the 
JRIT

15,1

12

instrument was pilot-tested for its reliability. The pilot test included 30 first- and second-year student of the Yenagoa Study Centre of NOUN who will not be in the final sample. This was done to remove any ambiguity and to take every necessary correction.

The reliability of the instrument was confirmed by using Pearson correlation coefficient using the IBM Statistical Package for the Social Sciences (SPSS) Base Version 22.0. The reliability coefficients obtained from the pilot study for the three subscales ranged from 0.765 to 0.809 (Table 1). This is a clear indication that the scales adapted for the study were found to be reliable in measuring e-learning readiness, individual innovativeness and e-learning selfefficacy of first- and second-year students of the Yenagoa Study Centre of NOUN.

\section{Respondents data}

For the about 476 questionnaires that were distributed, only 220 were retrieved which gives a recursive rate of $46.2 \%$. Three of the questionnaires were returned empty leaving the researcher with 217 valid responses which were included in the analysis. The socio demographic information of the respondents is as shown in Table 2.

\section{Hypothesis testing}

H1. There is no significant relationship between individual innovativeness and e-learning readiness of first- and second-year students of the Yenagoa Study Centre of NOUN

The analysis testing the above hypothesis is shown in Table 3.

Table 3 reveals that the correlation between individual innovativeness and e-learning readiness as 0.700 . The observed $p$-value (sig) of 0.000 is less than the chosen alpha level of

Table 1.

Reliability

\begin{tabular}{lc}
\hline & Coefficient of reliability \\
\hline E-learning readiness & 0.805 \\
Individual innovativeness & 0.765 \\
E-learning self-efficacy & 0.787 \\
\hline
\end{tabular}

\begin{tabular}{lcc}
\hline Demographic & Frequency & Percentage \\
\hline Gender & & \\
Male & 130 & 59.9 \\
Female & 87 & 40.1 \\
Year of study & & \\
First-year students & 100 & 46.1 \\
Second-year students & 117 & 53.9 \\
\hline
\end{tabular}

Table 3.

Test of significance of correlation of individual innovativeness and e-learning readiness

\begin{tabular}{lcccccccc}
\hline & & & & & $p-$ & Alpha \\
& $N$ & df & $r$ & value & level & Decision \\
\hline $\begin{array}{l}\text { VAR001 (individual innovativeness) and VAR003 } \\
\text { (e-learning readiness) }\end{array}$ & 217 & 215 & 0.700 & 0.000 & 0.05 & Sig \\
\hline
\end{tabular}


$0.05, r(215)=0.000, p<0.05$. Therefore, the null hypothesis of there is no significant relationship between individual innovativeness and e-learning readiness of first- and secondyear students of the Yenagoa Study Centre of NOUN is rejected. The implication is that, there is a significant relationship between individual the innovativeness and e-learning readiness of first- and second-year students of the Yenagoa Study Centre of NOUN.

H2. There is no significant relationship between the self-efficacy and e-learning readiness of first- and second-year students of the Yenagoa Study Centre of NOUN.

The correlation coefficient is shown in Table 4.

It can be discerned from Table 4, the observed probability value ( $p$-value) (sig) is 0.000 which is less than the chosen alpha value of $0.05, r(215)=0.000, p<0.05$. Therefore, the null hypothesis of there is no significant relationship between the self-efficacy and e-learning readiness of first- and second-year students of the Yenagoa Study Centre of NOUN is rejected. The alternative hypothesis of there is significant relationship between the self-efficacy and e-learning readiness of first- and second-year students of the Yenagoa Study Centre of NOUN is upheld.

H3. There is no joint relationship between individual innovativeness, self-efficacy and the e-learning readiness of first- and second-year students of the Yenagoa Study Centre of NOUN.

The $F$-statistics of multiple regression analysis of the joint relationship is shown in Table 5 .

It can be deduced from Table 5 above that the observed $p$-value (sig) 0.000 is less than the chosen alpha level of $0.05, F(2,214)=0.000, p<0.05$. Therefore, the null hypothesis of there is no joint relationship between individual innovativeness, self-efficacy and e-learning readiness of first- and second-year students of the Yenagoa Study Centre of NOUN is rejected. Conversely, the alternative hypothesis of there is a significant joint relationship between individual innovativeness, self-efficacy and e-learning readiness of first- and secondyear students of the Yenagoa Study Centre of NOUN is upheld.

H4. There is no significance difference in the e-learning readiness of male and female students of the Yenagoa Study Centre of NOUN.

The $t$-test analysis of the e-learning readiness of male and female students of the Study Centre is shown in Table 6.

\begin{tabular}{lcccccccc}
\hline & & & & & $p-$ & $\begin{array}{c}\text { Alpha } \\
\text { level }\end{array}$ & Decision \\
\hline $\begin{array}{l}\text { VAR002 (self-efficacy) and VAR003 (e-learning } \\
\text { readiness) }\end{array}$ & 217 & 215 & 0.317 & 0.000 & 0.05 & Sig
\end{tabular}

Innovativeness, self-efficacy and e-learning 
JRIT

15,1

14
Deducing from Table 6, the observed $p$-value (sig.) of 0.000 is less than the chosen alpha level of $0.05, t(215)=0.000<0.05$. Since the observed alpha level, the null hypothesis of there is no significance difference in the e-learning readiness of male and female students of the Yenagoa Study Centre of NOUN is rejected. On the other hand, the alternative hypothesis of there is a significance difference in the e-learning readiness of male and female students of the Yenagoa Study Centre of NOUN is upheld. It implies that male students of the sample of the study are more e-learning ready than their female colleagues.

\section{Discussion}

This study sought to determine the e-learning readiness of first-and second-year students of the Yenagoa Study Centre of the National Open University of Nigeria. It also explored the relationships between individual innovativeness, self-efficacy and the e-learning readiness of the study context. Consequently, based on the finding from the data, the summary of the discussion is that:

(1) Given the high correlation (0.700), it was established that there was a strong positive significant relationship between individual innovativeness and e-learning readiness of first- and second-year students of the Yenagoa Study Centre of NOUN. This was consistent with previous studies where individual innovativeness showed positive relationship with e-learning readiness (Ayub et al., 2017; Kusumaningtyas, 2019; Salloum et al., 2019; Yilmaz and Bayraktar, 2014). The implication of this is that high levels of individual innovativeness predict intentions to accept new technologies, in this case, the willingness to accept e-learning. This position is in tandem with the works of Rosen (2005) who found individual innovativeness to be predicting technology acceptance within the domain of information technology and Gürkan and Demiralay (2016) whose study indicated that individual innovativeness levels of surgeons significantly determined lead users among surgeons with respect to their adoption of new surgical instruments. Personal innovativeness in the domain of information technology is a technology acceptance framework. It was shown that PIIT was statistically significant in predicting user intentions, and that it could be practically significant as well.

(2) A statistically significant relationship also existed between e-learning self-efficacy scores and the e-learning readiness of the respondents. This confirms findings from other studies. For example, a study by Nyagorme (2018) asserted that self-efficacy critical in determining the degree of involvement in e-learning usage by ODL students, as an empirical study conducted by the author at the University of Cape Coast actually found perceived e-learning self-efficacy as key predictor to e-learning adoption. Similar results were obtained by other researchers who confirm that e-learning self-efficacy predicts students' tendency to be more determined to succeed in online courses (Ayub et al., 2017; Zimmerman and Kulikowich, 2016). A study of teachers by Tweed (2013) similarly confirmed significant association between selfefficacy and technology adoption in the classroom. It is an indication that respondents with stronger beliefs in their capabilities to learning in digital

Table 6.

$T$-test analysis of the e-learning readiness of male and female students of the Yenagoa study centre of NOUN

\begin{tabular}{lrrrccccc}
\hline Variable & $N$ & $\dot{x}$ & SD & DF & $T$ & $p$-value (sig.) & Alpha level & Decision \\
\hline Male & 130 & 87.01 & 12.03 & 215 & 6.82 & 0.000 & 0.05 & sig \\
Female & 87 & 76.79 & 8.68 & & & & & \\
\hline
\end{tabular}


environments and other electronic media have stronger tendencies to sustain learning at the National Open University of Nigeria.

(3) Contrary to the hypothesis three: that there was not significant joint relationship between individual innovativeness, e-learning self-efficacy and the e-learning readiness of first- and second year students of the Yenagoa Study Centre of NOUN, there is indeed a statistically significant joint relationship between the three variables under investigation. This confirms results of previous research by Ayub et al. (2017) whose study also looked at self-efficacy and individual innovativeness.

Innovativeness, self-efficacy and e-learning investigated the effect of computer self-efficacy, individual innovativeness and ICT mediated learning environment.

(4) The null hypothesis (H4) states there is no statistically significant difference between the gender of the respondents and their e-learning readiness. Whereas this position has been confirmed by a few studies which found that the gender of the respondents does not seem to display any effect to the e-learning readiness (Gay, 2018; Hashim and Tasir, 2014; Tweed, 2013), contrary to the null hypothesis, the current study found strong positive relationship between gender and e-learning readiness. These results are equally consistent with findings from several previous studies which found gender differences in the levels of e-learning readiness scores or technology acceptance among students of higher educational institutions (Adams et al., 2018; Bana et al., 2015; Formoso, 2018; González-Gómez et al., 2012; Nyagorme, 2018; Ramírez-Correa et al., 2015; Walia et al., 2019). However, unlike the studies by Adams et al. (2018), Formoso (2018) which found female students to be possessing higher online learning readiness, results from this study showed that male students of the were more e-learning ready than their female colleagues. This is consistent with results from recent studies which indicated that male respondents were more comfortable with learning technologies and therefore were more likely to learn actively with learning management systems (Arkorful, 2019; Binyamin et al., 2020; Kanwal et al., 2020; Namirembe, 2020).

\section{Conclusion}

E-learning as a technology-enhanced approach to education has become a central feature in the successful running of ODL educational mode. Similarly, e-learning readiness enhances the ability of learners in ODL institutions to persevere and complete their studies. Hence, to harness the full potential of electronic learning as an educational strategy to increase broader access to tertiary education in Nigeria, to augment classroom instruction and eventually intensify students' learning outcomes in distance learning institutions like the National Open University of Nigeria, it is imperative that we investigate the factors students perceive as significant in their adoption of ELS, as this helps in predicting the sustainability of e-learning programmes. Consequently, this study was aimed at determining the e-learning readiness of first- and second-year students of the Yenagoa Study Centre of NOUN. It specifically sought to explore the relationship between individual innovative and e-learning readiness, between self-efficacy and e-learning readiness, investigate if a joint association existed between individual innovativeness, e-learning self-efficacy and e-learning readiness, as well as to ascertain if gender differences and class differences had impact in the e-learning readiness of the respondents.

The results of the statistical analysis presented in this dissertation were built on five research questions and five corresponding null hypotheses formulated and presented in Chapters 1 and 4. The first two research questions were analysed using Pearson Product 
JRIT

15,1

Moment Correlation, the third was analysed with multiple regression while the remaining two research questions were analysed by adopting independent sample $t$-tests.

The total number of respondents in the study was 217, out of which 100 were first-year and 117 second-year students of the Yenagoa Study Centre of the National Open University of Nigeria. At the 95\% confidence level, statistical tests confirm significant relationships between individual innovativeness and e-learning readiness. Same was observed between e-learning self-efficacy and e-learning readiness. It implies that individual innovativeness and e-learning self-efficacy were confirmed to be antecedents of e-learning readiness. Significant differences were also observed in the e-learning readiness of male and female respondents.

The conclusion of study is that, individual innovativeness and e-learning self-efficacy have a crucial role to play in determining an individual's willingness to use e-learning resources and to actively participate in virtual learning environment or even in ODL education such as the National Open University of Nigeria. Equally, the gender of respondents was discovered to have played a key role in their e-learning readiness as male students had higher e-learning readiness scores. Finally, the findings in this study largely support the extant literature.

\section{Practical implications}

The implications for this study are that, people who are innately innovative will willingly accept technology and by extension, learning in technology rich environments like that found in the National Open University whose mode of study is blended learning inherently found in ODL institution. Therefore, this study is significant as it will provide relevant information to the management and administrators of the National Open University of Nigeria, policymakers and regulatory institutions for the development, deployment and implementation of e-learning strategies. Findings and recommendations to be presented to NOUN will also benefit e-learning initiatives undertaken by similar institutions that adopt the ODL mode of education in Nigeria and other developing countries.

\section{Limitation and future studies}

Like every other study of this nature, this one also suffers some limitations. First, NOUN is a very large university with over half a million students spread across almost 78 study centres. This means that observation from just one study centre amounts to a very small sample size. This according to Schweighofer et al. (2019) jeopardises the generalisability and validity of study results. The authors also maintain that empirical data generated from surveys that usually rely participants' abilities to read and select responses without further interpretation by the researchers suffer from cognitive biases like social desirability. To address the above limitations, detailed studies involving all studies centres of NOUN be undertaken and other qualitative and or mixed research methodologies be adopted in the future.

\section{References}

Adams, D., Sumintono, B., Mohamed, A. and Noor, N.S.M. (2018), "E-learning readiness among students of diverse backgrounds in a leading Malaysian higher education institution", Malaysian Journal of Learning and Instruction, Vol. 15 No. 2, pp. 227-256.

Adigüzel, A. (2012), "The relation between candidate teachers' moral maturity levels and their individual innovativeness characteristics: a case study of Harran university education faculty", Educational Research and Reviews, Vol. 7 No. 25, pp. 543-547.

Adiyarta, K., Napitupulu, D., Rahim, R., Abdullah, D. and Setiawan, M. (2018), “Analysis of e-learning implementation readiness based on based on integrated ELR model", Journal of Physics: Conference Series, Vol. 1007, doi: 10.1088/1742-6596/1007/1/012041. 
Agarwal, R. and Prasad, J. (1998), "A conceptual and operational definition of personal innovativeness in the domain of information technology", Information Systems Research, Vol. 9 No. 2, pp. 204-215.

Aldahdouh, T.Z., Nokelainen, P. and Korhonen, V. (2020), "Technology and social media usage in higher education: the influence of individual innovativeness", SAGE Open, Vol. 10 No. 1, pp. 1-20, doi: 10.1177/2158244019899441.

Arkorful, V. (2019), "Gender perception on the effectiveness of u-learn management system as an e-learning platform for distance education”, Journal of Learning and Teaching in Digital Age, Vol. 5 No. 2, pp. 35-45.

Aydin, C. and Tasci, D. (2005), "Measuring readiness for e-learning: reflections from an emerging country", Educational Technology and Society, Vol. 8 No. 4, pp. 244-257.

Ayub, A.F.M., Zaini, S.H., Luan, W.S. and Jaafar, W.M.W. (2017), "The influence of mobile self-efficacy, personal innovativeness and readiness towards students' attitudes towards the use of mobile apps in learning and teaching", International Journal of Academic Research in Business and Social Sciences, Vol. 7 No. 4, pp. 364-374.

Bai, X. (2017), "Promote technology self-efficacy via a SCORM-based e-learning approach", International Journal of Information and Education Technology, Vol. 7 No. 8, pp. 575-580.

Bana, C., Romasame, J.R. and Cristobal, E. (2015), "Gender disaggregated analysis of the e-learning readiness state of students in a public higher education institution", Proceedings of the 12th International Conference on eLearning for Knowledge-Based Society, pp. 18.1-18.7.

Bandura, A. (1977), "Self-efficacy: toward a unifying theory of behavioral change", Psychological Review, Vol. 84 No. 2, pp. 191-215.

Bandura, A. (1982a), “The assessment and predictive generality of self-percepts of efficacy”, Journal of Behavior Therapy and Experimental Psychiatry, Vol. 13 No. 3, pp. 195-199.

Bandura, A. (1982b), "Self-efficacy mechanism in human agency", American Psychologist, Vol. 37 No. 2, pp. 122-147.

Bandura, A. (1994), "Self-efficacy", in Ramachaudran, V. (Ed.), Encyclopedia of Human Behaviour, Academic, Press, New York, NY, Vol. 4, pp. 71-81.

Bandura, A. (1997), Self-Efficacy: The Exercise of Control, Worth Publishers, New York, NY.

Bandura, A. and Adams, N. (1977), "Analysis of self-efficacy theory of behavioral change", Cognitive Therapy and Research, Vol. 1 No. 4, pp. 287-310.

Bautista, R.G., Valdez, C.C.T., Garingan, E.G., Camayang, L.G., Horlador, D.N.P., Manait, J.N. and Reyes, E.S. (2018), "Individual innovativeness of pre-service elementary grade teachers", American Journal of Educational Research, Vol. 6 No. 6, pp. 617-620.

Bawa, P. (2016), "Retention in online courses: exploring issues and solutions-a literature review", SAGE Open, Vol. 6 No. 1, pp. 1-11, doi: 10.1177/2158244015621777.

Binyamin, S.S., Rutter, M.J. and Smith, S. (2020), "The moderating effect of gender and age on the students' acceptance of learning management systems in Saudi higher education”, Knowledge Management \& ELearning, Vol. 12 No. 1, pp. 30-62.

Borotis, S. and Poulymenakou, A. (2004), "E-learning readiness components: key issues to consider before adopting e-learning interventions", Proceedings of eLearn 2004 Conference, pp. 1622-1629.

Çelik, K. (2013), "The relationship between individual innovativeness and self-efficacy levels of student", International Journal of Scientific Research in Education, Vol. 6 No. 1, pp. 56-67.

Chen, Y.-L. (2014), "A study on student self-efficacy and technology acceptance model within an online task-based learning environment”, Journal of Computers, Vol. 9 No. 1, pp. 34-43.

Christensen, R. and Knezek, G. (2015), "The technology proficiency self-assessment questionnaire (TPSA): evolution of a self-efficacy measure for technology integration”, in Brinda, T., Reynolds, N., Romeika, R. and Schwill, A. (Eds), Proceedings of the KEYCIT2014: Key Competencies in Informatics and ICT Conference, KEYCIT, Potsdam, pp. 311-318. 
JRIT

15,1

Chu, R.J.-C. and Tsai, C.-C. (2009), "Self-directed learning readiness, Internet self-efficacy and preferences towards constructivist Internet-based learning environments among higher-aged adults", Journal of Computer Assisted Learning, Vol. 25 No. 5, pp. 489-501.

Coklar, A. (2012), "Individual innovativeness levels of educational administrators", Digital Education Review, Vol. 22, pp. 100-110.

Ditimi, A. and Ayanda, D. (2013), "A comparative analysis of e-readiness assessment in Nigerian private universities and its impact on educational development", Information and Knowledge Management, Vol. 3 No. 11, pp. 30-37.

Drumm, L. (2019), "Folk pedagogies and pseudo-theories: how lecturers rationalise their digital teaching”, Research in Learning Technology, Vol. 27, doi: 10.25304/rlt.v27.2094.

Ekundayo, M. and Ekundayo, J. (2009), "Capacity constraints in developing countries: a need for more e-learning space? The case of Nigeria", in Atkinson, R. and McBeath, C. (Eds), Same Places, Different Spaces. Proceedings of the 26th Australasian Society for Computers in Learning in Tertiary Education (ASCILITE), ASCILITE, Auckland, pp. 243-255.

Formoso, D.B. (2018), "Readiness of tertiary level students of holy angel university to enroll in online learning”, Elixir Educational Technology, Vol. 120, pp. 51370-51375.

Frank, M. (2001), Self-efficacy: The Key to Success in Sports, available at: https:/www.excelatlife.com/ questionnaires/self-efficacy.php (accessed 26 June 2019).

Frank, M. (2019), The Pillars of the Self-Concept: Self-Esteem and Self-Efficacy, available at: https:// www.excelatlife.com/articles/selfesteem.htm (accessed 25 June 2019).

Gaumer Erickson, A. and Noonan, P. (2018), Self-efficacy formative questionnaire, The Skills that Matter: Teaching Interpersonal and Intrapersonal Competencies in any Classroom, Corwin, Thousand Oaks, CA, pp. 175-176.

Gay, G. (2018), "Fixing the 'ready' in e-learning readiness", in Sinecen, M. (Ed.), Trends in E-Learning, Intech Open, London, pp. 65-83, doi: 10.5772/intechopen.74287.

Gilbert, D. (2007), “What drives and sustains firm innovativeness?”, 21st ANZAM Conference, Sydney, available at: http://www.anzam.org/wp-content/uploads/pdf-manager/1849_GILBERTDAVID_ 389.PDF (accessed 16 October 2016).

González-Gómez, F., Guardiola, J., Rodríguez, O.M. and Alonso, M.A.M. (2012), "Gender differences in e-learning satisfaction”, Computers and Education, Vol. 58 No. 1, pp. 283-290.

Gürkan, G.Ç. and Demiralay, T. (2016), "Individual innovativeness levels of lead users and non-lead users: the case study of surgeons in Turkey", International Journal of Business and Social Science, Vol. 7 No. 7, pp. 114-121.

Hashim, H. and Tasir, Z. (2014), "E-learning readiness: a literature review", International Conference on Teaching and Learning in Computing and Engineering, IEEE, Kuching, pp. 267-271, doi: 10. 1109/LaTiCE.2014.58.

Hendarman, A. and Cantner, U. (2018), "Soft skills, hard Skills, and individual innovativeness", Eurasian Business Review, Vol. 8 No. 2, pp. 139-169.

Hodges, C. (2008), "Self-efficacy in the context of online learning environments: a review of the literature and directions for research", Performance Improvement Quarterly, Vol. 20 Nos 3-4, pp. 7-25.

Hong, J.-C., Hwang, M.-Y., Tai, K.-H. and Lin, P.-H. (2019), "Improving cognitive certitude with calibration mediated by cognitive anxiety, online learning self-efficacy and interest in learning Chinese pronunciation", Educational Technology Research and Development, Vol. 67 No. 3, pp. 597-615.

Hurt, H.T., Joseph, K. and Cook, C. (1977), "Scales for the measurement of innovativeness", Human Communication Research, Vol. 4 No. 1, pp. 58-65.

Joo, Y., Bong, M. and Choi, H. (2000), "Self-efficacy for self-regulated learning, academic self-efficacy, and Internet self-efficacy in web-based instruction", Educational Technology Research and Development, Vol. 48 No. 2, pp. 5-17. 
Kanwal, F., Rehman, M. and Asif, M.M. (2020), "E-learning adoption and acceptance in Pakistan: moderating effect of gender and experience", Mehran University Research Journal of Engineering and Technology, Vol. 39 No. 2, pp. 324-341.

Kelly, D. (2017), Measurements of Self-Efficacy in Engineering Graphics Students: An Examination of Factors Measurements of Self-Efficacy in Engineering Graphics Students: An Examination of Factors, North Carolina State University, Raleigh, PhD dissertation.

Kilicer, K., Bardakci, S. and Arpac1, I. (2018), "Investigation of emerging technology usage characteristics as predictors of innovativeness", Contemporary Educational Technology, Vol. 9 No. 3, pp. 225-245.

Kusumaningtyas, F. (2019), The Effect of Computer Self-Efficacy, Personal Innovativeness, and Learning Environment Toward Mastery of Information and Communication Technology, Undergraduate dissertation, Yogyakarta State University, Yogyakarta.

Kyari, S., Adiuku-Brown, M., Abechi, H. and Adelakun, R. (2018), "E-learning in tertiary education in Nigeria: where do we stand?", International Journal of Education and Evaluation, Vol. 4 No. 9, pp. 1-10.

Lai, M.-L. (2008), "Technology readiness, internet self-efficacy and computing experience of professional accounting students", Campus-Wide Information Systems, Vol. 25 No. 1, pp. 18-29.

Lee, J.-W. and Mendlinger, S. (2011), "Perceived self-efficacy and its effect on online learning acceptance and student satisfaction", Journal of Service Science and Management, Vol. 4 No. 3, pp. 243-252.

Martins, C. (2018), “The individual innovativeness theory: a framework to investigate teachers' views on technology", ICICTE 2018 Proceedings, pp. 360-370.

Miltiadou, M. and Ho, C. (2000), "Validation of the online technologies self-efficacy scale (OTSES)", Paper Presented at the AECT International Convention, Denver CO. (ERIC Document Reproduction Service No. ED 445 672).

Mooij, T. and Smeets, E. (2001), "Modelling and supporting ICT implementation in secondary schools", Computers \& Education, Vol. 36 No. 3, pp. 265-281.

Musaka, M. (2015), The Effect of Technology Self-Efficacy and Personal Engagement on Students' and Teachers' Attitudes Toward Technology Use in Education, A PhD dissertation, Reich College of Education, Boone.

Namirembe, E. (2020), E-learning in Universities in Uganda: Predictors of Successful Adoption, $\mathrm{PhD}$ dissertation, University of Cape Town, Cape Town.

Nardi, A. and Ranieri, M. (2019), "Comparing paper-based and electronic multiple-choice examinations with personal devices: impact on students' performance, self-efficacy and satisfaction”, British Journal of Educational Technology, Vol. 50 No. 3, pp. 1495-1506.

Naresh, B., Reddy, B.S. and Pricilda, U. (2016), "A study on the relationship between demographic factor and e-learning readiness among students in higher education", SONA Global Management Review, Vol. 10 No. 4, pp. 1-11.

National Commission for Colleges of Education (2019), available at: http://www.ncceonline.edu.ng/ colleges.php (accessed 24 May 2019).

National Board for Technical Education (2019), available at: https://net.nbte.gov.ng/accredited\% 20institutions.

NBS (2019), JAMB Applications and Admitted Candidates by State and Gender within Faculty (2017 2018), Nigerian Bureau of Statistics, Abuja.

Nigerian Universities Commission (2019), available at: https:/nuc.edu.ng/.

Nyagorme, P. (2014), E-learning adoption and utilisation: a comparative study of Kenyatta University, Kenya and University of Cape Coast, Ghana, $\mathrm{PhD}$ Thesis, Kenyatta University, Nairobi.

Nyagorme, P. (2018), "E-learning perceived usefulness, self-efficacy and attitude of distance learners and e-learning uptake at the college of distance education", University of Cape Coast. IMPACT: International Journal of Research in Engineering \& Technology, Vol. 6 No. 1, pp. 15-26. 
JRIT

15,1

Obi, I., Charles-Okoli, A., Agunwa, C., Omotowo, B., Ndu, A. and Agwu-Umahi, O. (2018), "E-learning readiness from perspectives of medical students: a survey", Nigerian Journal of Clinical Practice, Vol. 21 No. 3, pp. 293-300.

Okagbue, H.I., Bishop, S.A., Boluwajoko, A.E., Ezenkwe, A.M., Anene, G.N., Akinsola, B.E. and Offiah, I.B. (2020), "Gender and age differences in the study plan of university students", International Journal of Interactive Mobile Technologies, Vol. 14 No. 1, pp. 62-81.

Oketch, H., Njihia, J. and Wausi, A. (2014), "E-learning readiness assessment model in Kenya's higher educational institutions: a case study of university of Nairobi”, International Journal of Scientific Knowledge, Vol. 5 No. 6, pp. 29-41.

Olivier, E., Archambault, I., De Clercq, M. and Galand, B. (2019), "Student self-efficacy, classroom engagement, and academic achievement: comparing three theoretical frameworks", Journal of Youth and Adolescence, Vol. 48 No. 2, pp. 326-340.

Olowonisi, V. (2016), "Harnessing the opportunities of e-learning and education in promoting literacy in Nigeria", International Journal of Educational and Pedagogical Sciences, Vol. 10 No. 9, pp. 3205-3208.

Omoike, M. (2020), NOUN Student Population Hits 550,000, as FG Targets 1 Million, available at: https://nnn.com.ng/noun-student-population-hits-550000-as-fg-targets-1-million/.

Omoyibo, K.U., Egharevba, E.M. and Iyanda, O.E. (2010), "The position and empowerment of women in rural Nigeria: the gender implication”, Gender and Behaviour, Vol. 8 No. 2, pp. 3363-3378.

Ong, C.-S. and Lai, J.-Y. (2006), "Gender differences in perceptions and relationships among dominants of e-learning acceptance", Computers in Human Behaviour, Vol. 22 No. 5, pp. 816-829.

Ouma, G., Awuor, F. and Kyambo, B. (2013), "E-learning readiness in public secondary schools in Kenya”, European Journal of Open, Distance and e-Learning, Vol. 16 No. 2, pp. 97-110.

Park, J. and Kim, H. (2010), "Impacts of individual innovativeness on the acceptance of IT-based innovations in health care fields", Healthcare Informatics Research, Vol. 16 No. 4, pp. 290-298.

Parlakkılıç, A. (2015), "E-learning readiness in medicine: Turkish FAMILY Medicine (FM): physicians' case", The Online Journal of Distance Education and e-Learning, Vol. 3 No. 3, pp. 21-25.

Pituch, K.A. and Lee, Y. (2006), "The influence of system characteristics on e-learning use”, Computers and Education, Vol. 47 No. 2, pp. 222-44.

Premium Times (2018), Nigeria: Enrolment at Nigeria's National Open University Hits 515,000, available at: https://allafrica.com/stories/201811260814.html (accessed 15 May 2018).

Prior, D., Mazanov, J., Meacheam, D., Heaslip, G. and Hanson, J. (2016), “Attitude, digital literacy and self-efficacy: flow-on effects for online learning behaviour", Internet and Higher Education, Vol. 29, pp. 91-97.

Puzziferro, M. (2008), "Validation of the online technologies self-efficacy scale (OTSES)", The American Journal of Distance Education, Vol. 22, pp. 72-89.

Quintero, J.M. (2020), I Think I Can; I Know I Can: Self-Efficacy as an Indicator of Learner SelfSatisfaction with the Learning Experience in an Online Master of Social Work Program, $\mathrm{PhD}$ dissertation, Texas State University, San Marcos.

Rahardjo, D. (2018), "E-learning readiness and technology adoption in online tutorial", Proceedings of the 32nd Annual Conference of the Asian Association of Open Universities (AAOU) 2018: Open Education in Human Resource Development in Asia's Period of Integration", Hanoi, Vietnam.

Ramírez-Correa, P.E., Arenas-Gaitán, J. and Rondán-Cataluña, F.J. (2015), "Gender and acceptance of e-learning: a multi-group analysis based on a structural equation model among college students in Chile and Spain", PloS One, Vol. 10 No. 10, e0140460.

Rasouli, A., Rahbania, Z. and Attaran, M. (2016), "Students' readiness for e-learning application in higher education”, Malaysian Online Journal of Educational Technology, Vol. 4 No. 3, pp. 51-64.

Rogers, E. (1995), Diffusion of Innovations, The Free Press, New York, NY. 
Rohayani, A., Kurniabudi, K. and Sharipuddin, S. (2015), "A literature review: readiness factors to measuring e-learning readiness in higher education”, Procedia Computer Science, Vol. 59, pp. 230-234.

Rosen, P.A. (2005), The effect of personal innovativeness on technology acceptance and use, $\mathrm{PhD}$ Thesis, Oklahoma State University, Oklahoma.

Sadi, O. and Uyar, M. (2013), "The relationship between self-efficacy, self-regulated learning strategies and achievement: a path model”, Journal of Baltic Science Education, Vol. 12 No. 1, pp. 21-33.

Salloum, S., Al-Emran, M., Shaalan, K. and Tarhini, A. (2019), "Factors affecting the E-learning acceptance: a case study from UAE", Education and Information Technologies, Vol. 24 No. 1, pp. 509-530.

Schreurs, J., Ehlers, U.-D. and Sammour, G. (2008), "E-learning readiness analysis (ERA): an e-health case study of e-learning readiness", International Journal of Knowledge and Learning, Vol. 4 No. 5 , pp. 496-508.

Schunk, D.H. (1995), "Self-efficacy, motivation, and performance", Journal of Applied Sport Psychology, Vol. 7 No. 2, pp. 112-137.

Schwarzer, R. and Jerusalem, M. (1995), "Generalized self-efficacy scale”, in Weinman J., Wright S. and Johnston M. (Eds), Measures in Health Psychology: A User's Portfolio. Causal and Control Beliefs, NFER-NELSON, Windsor, pp. 35-37.

Schweighofer, P., Weitlaner, D., Ebner, M. and Rothe, H. (2019), "Influential factors for technologyenhanced learning: professionals' views", Journal of Research in Innovative Teaching and Learning, Vol. 12 No. 3, pp. 268-294.

Shea, P. and Bidjerano, T. (2010), "Learning presence: towards a theory of self-efficacy, self-regulation, and the development of a communities of inquiry in online and blended learning environments", Computers \& Education, Vol. 55 No. 4, pp. 1721-1731.

Shen, D., Cho, M.-H., Tsai, C.-L. and Marra, R. (2013), "Unpacking online learning experiences: online learning self-efficacy learning satisfaction”, Internet and Higher Education, Vol. 19, pp. 10-17.

Taipjutorus, W., Hansen, S. and Brown, M. (2012a), "Investigating a relationship between learner control and self-efficacy in an online learning environment", Journal of Open and Flexible Distance Learning, Vol. 16 No. 1, pp. 56-69.

Taipjutorus, W., Hansen, S. and Brown, M. (2012b), "Improving learners' self-efficacy in a learnercontrolled online learning environment: a correlational study", in Brown, M. Hartnett, \& T. Stewart (Eds), Future Challenges, Sustainable Futures. Proceedings ASCILITE 2012, ASCILITE, Wellington, pp. 907-911.

Tweed, S.R. (2013), Technology implementation: teacher age, experience, self-efficacy, and professional development as related to classroom technology integration, $\mathrm{PhD}$ Thesis, East Tennessee State University, Johnson City.

Vilkas, B. and McCabe, C. (2014), Promoting Students' Self-Efficacy in the Online Classroom, available at: https://www.facultyfocus.com/articles/online-education/promoting-students-self-efficacyonline-classroom/ (accessed 3 July 2019).

Walia, P., Tulsi, P. and Kaur, A. (2019), "Student readiness for online learning in relation to gender and stream of study", Proceedings of IEEE Learning with MOOCS Conference, Milwaukee, pp. 21-25, doi: 10.1109/LWMOOCS47620.2019.8939651.

Yi, M.Y., Fiedler, K.D. and Park, J.S. (2006), "Understanding the role of individual innovativeness in the acceptance of IT-based innovations: comparative analyses of models and measures", Decision Sciences, Vol. 7 No. 3, pp. 393-426.

Yilmaz, O. and Bayraktar, D. (2014), "Teachers' attitudes towards the use of educational technologies and their individual innovativeness categories", Procedia - Social and Behavioral Sciences, Vol. 116 No. 2014, pp. 3458-3461. 
JRIT 15,1

Yildiz Durak, H. (2018), "Flipped learning readiness in teaching programming in middle schools: modelling its relation to various variables", Journal of Computer Assisted Learning, Vol. 34 No. 6, pp. 939-959.

Yokoyama, S. (2019), "Academic self-efficacy and academic performance in online learning: a mini review”, Frontiers in Psychology, Vol. 9, doi: 10.3389/fpsyg.2018.02794, Article 2794.

Yunusa, A., Umar, I. and Bervell, B. (2019), "Octennial review (2010-2018) of literature on M-learning for promoting distributed-based medical education in sub-Saharan Africa", International Review of Research in Open and Distributed Learning, Vol. 20 No. 2, pp. 279-301.

Zimmerman, W. and Kulikowich, J. (2016), "Online learning self-efficacy in students with and without online learning experience”, American Journal of Distance Education, Vol. 30 No. 3, pp. 180-191.

\section{Further reading}

Kim, H., Hong, A. and Song, H.-D. (2019), "The roles of academic engagement and digital readiness in students' achievements in university e-learning environments", International Journal of Educational Technology in Higher Education, Vol. 16 No. 21, available at: https:// educationaltechnologyjournal.springeropen.com/track/pdf/10.1186/s41239-019-0152-3 (accessed 5 July 2019).

Mao, J. (2014), "Social media for learning: a mixed methods study on high school students' technology affordances and perspectives", Computers in Human Behavior, Vol. 33, pp. 213-223.

Moses, T., Oladunjoye, J. and Agu, E. (2016), "Comparative study of e-learning experiences: a case study of Nigeria, South Africa and United States", International Journal of Grid and Distributed Computing, Vol. 9 No. 10, pp. 161-172.

Revelo, R., Schmitz, C., Le, D. and Loui, M. (2017), "Self-efficacy as a long-term outcome of a general education course on digital technologies", IEEE Transactions on Education, Vol. 60 No. 3, pp. 198-204.

Yang, K. (2010), "The effects of technology self-efficacy and innovativeness on consumer mobile data service adoption between American and Korean consumers", Journal of International Consumer Marketing, Vol. 22 No. 2, pp. 117-127.

\section{Corresponding author}

Gordon Monday Bubou can be contacted at: gbubou@gmail.com

For instructions on how to order reprints of this article, please visit our website:

www.emeraldgrouppublishing.com/licensing/reprints.htm

Or contact us for further details: permissions@emeraldinsight.com 